EUROPA REGIONUM TOM XXVIII ROK 2016

DOI: $10.18276 /$ er.2016.28-21

MARLENA PROCHOROWICZ

Zachodniopomorski Uniwersytet Technologiczny w Szczecinie

\title{
Rola mediów w propagowaniu turystyki i rekreacji
}

\section{Wprowadzenie}

$\mathrm{M}$ edia stanowią podstawową funkcję w przekazywaniu informacji masowemu odbiorcy. Do mediów zaliczymy: prasę, radio, telewizję, Internet, a także książki, płyty, filmy. Media to także instytucje, które rozpowszechniają informacje, a mianowicie wszelkiego rodzaju wydawnictwa oraz agencje prasowe. Obecnie nie wyobrażamy sobie przekazywania informacji bez komunikowania się $\mathrm{z}$ innymi osobami za pośrednictwem mediów społecznościowych, które w ostatnim czasie tak bardzo się rozwinęły.

Zasady funkcjonowania mediów w Polsce określone są w konstytucji, a Art. 54 zapewnia każdemu wolność słowa, a także zdobywanie i rozpowszechnianie informacji. Wszystkie prawne regulacje, które dotyczą działania mediów w Polsce są zgodne z: Międzynarodowym Paktem Praw Obywatelskich i Politycznych, Europejską Konwencją o Ochronie Praw Człowieka i Podstawowych Wolnościach oraz Europejską Konwencją o Telewizji Ponadgranicznej.

W Polsce na straży ładu w sferze mediów stoi Krajowa Rada Radiofonii i Telewizji, natomiast dziennikarze powołali do życia Radę Etyki Mediów, do zadań której należy obrona wolności słowa i mediów.

Główne zadania mediów, to:

- dostarczanie informacji,

- umożliwienie korzystania $\mathrm{z}$ dorobku kulturalnego oraz $\mathrm{z}$ wyników badań,

- popieranie krajowej twórczości audiowizualnej, 
- dostarczanie rozrywki (Sapeta, 2008).

W Polsce środki masowego przekazu zaczęły rozwijać się w XIX w. (prasa), w XX w. bardzo rozwinął się film (lata 20.), radio (lata 30.) i telewizja (lata 50.), ale termin mass media powstał w USA już w latach 40. i określały masowy charakter produkcji i odbioru przekazu.

Środki masowego przekazu można sklasyfikować ze względu na ich niejednolitą siłę oddziaływania Wśród środków masowych można wyróżnić takie, które oddziałują na odbiorców za pośrednictwem: wzroku (książka, prasa), słuchu (radio), słuchu i wzroku (telewizja i film dźwiękowy).

$\mathrm{W}$ artykule przedstawiona zostanie rola mediów, głównie w propagowaniu turystyki i rekreacji. Firmie czy instytucji zajmującej się usługami noclegowymi, transportowymi, gastronomic znymi, rekreacyjnymi, rehabilitacyjnymi, sportowymi zależy, by dotrzeć do jak najszerszej rzeszy odbiorców. Jednak trzeba zaznaczyć, że każdy wybiera takie medium, które najbardziej mu odpowiada i wcale nie jest prawdą, że trzeba korzystać ze wszystkich jakie są dostępne na naszym rynku. Wiąże się to również z ponoszonymi kosztami przez firmę.

W większości przedsiębiorców branży turystycznej istnieje przekonanie o konieczności wykorzystania nie tylko prasy, radia i telewizji do promocji usług i produktów turystycznych. By być konkurencyjnym, by szybciej powiadomić klienta o swojej ofercie i zaznaczyć swoją obecność wykorzystuje się media elektroniczne: portale miejskie, media społecznościowe, aplikacje mobilne (Biełuszko 2015). Mówiąc o mediach mamy na myśli radio i telewizję.

\section{Rodzaje i funkcje środków masowego przekazu}

Media mają ogromny wpływ na oddziaływanie odbiorcy, bardzo często ksztattują opinie, czasem manipulują, narzucają, wymuszają, dlatego często używa się pojęcia „czwarta władza”.

Media możemy podzielić na: media tradycyjne (np. film, książka, radio, telewizja), media interaktywne (np. Internet, telewizja cyfrowa, smart TV). Jeśli chodzi o szybkość przekazu to możemy podzielić je na: media wolnego kroku (prasa, książki) oraz media szybkiego kroku (radio, telewizja). W ostatnim czasie najszybszym medium stały się portale społecznościowe, głównie za sprawą Internetu. Nawet przyjęło się powiedzenie: ,...nie ma cię $w$ Internecie - nie istniejesz". Dziś prawie każda firma, czy instytucja posiada własną witrynę in- 
ternetową, by każdy poszukujący produktu bądź usługi sam mógł wybrać i skontaktować się z firmą. Media petnią wiele funkcji, między innymi:

- informacyjną - przekazują masowemu odbiorcy informacje, np. Internet i telewizja (Onet.pl, wp.pl, TVN24.pl, Polsat News, TVP Info),

- opiniotwórczą - kształtują opinię odbiorcy, poprzez ich dobór a także komentarze (Sposób wyeksponowania np. tytuł, wielkość czcionki, miejsce umieszczenia informacji) ma wpływ na wagę przekazywanej informacji. Media mogą się stać również narzędziem propagandy,

- kontrolną - pozwalają ocenić postępowanie jednostek, np. zajmujących wysokie państwowe stanowiska,

- kulturotwórczą - upowszechniają współczesną kulturę: koncerty, teatr telewizji, programy edukacyjne,

- edukacyjną - poszerzają wiedzę odbiorców, np.

- rekreacyjną - dostarczają odbiorcy rozrywkę. (Sapeta 2008).

Pamiętajmy, że media mogą nas wykreować, ale również mogą nas znis zczyć, dlatego z przedstawicielami mediów warto mieć dobre kontakty.

Celem istnienia mediów lokalnych według Kępy-Mętrak, jest realizowanie kilka funkcji:

- poznawczej, polegającej na dostarczaniu odbiorcom wiedzy o otaczającej rzeczywistości,

- perswazyjnej, pojmowanej jako kształtowanie odpowiednich postaw wobec tej rzeczywistości,

- kontrolnej, polegającej na sprawowaniu nadzoru nad różnymi przejawami życia społecznego, politycznego, gospodarczego, szczególnie na szczeblu władzy,

- motywacyjnej, pobudzającej społeczeństwo do różnych form aktywności, np. poprzez inicjowanie różnorodnych akcji,

- integracyjnej, mającej na celu włączanie ludzi w życie społeczne, skupianie wokół ważnych problemów,

- socjalizacyjnej, zwanej też wychowawczą, odwołującą się do pozytywnych wartości i wzorów postępowania,

- rozrywkowej, której celem jest dostarczanie przyjemności i relaksu. Funkcje te wzajemnie się przenikają i uzupełniają.

W rezultacie media lokalne nie tylko informują o wydarzeniach, ale także uczą i wychowują, kontrolują społeczeństwo i władze lokalne, przekonują i mo- 
tywują, zachęcają do działania, jednoczą albo czasem dzielą ludzi oraz dostarczają rozrywki. (Kępa-Mętrak 2015).

$\mathrm{Na}$ rynku wydawniczym jest około 3500 tytułów prasy lokalnej. Największy „wysyp” tytułów prasy lokalnej zaobserwowano w latach 1989-2005, wówczas to ukazało się 5374 tytułów lokalnych czasopism. Niestety ponad połowa nie przetrwała próby czasu, zwłaszcza, że oprócz prasy samorządowej, są to najczęściej prywatne media (Chorązki 2005).

Branża turystyczna dzieli się na wiele sektorów $\mathrm{m}$. in. turystyka biznesowa, turystyka towarzyska, turystyka rodzinna, turystyka religijna, turystyka edukacyjna, turystyka sportowa, turystyka zdrowotna czy turystyka gości z zagranicy. Badania ubiegłorocznego sezonu wykazują, że w 2014 r. do Polski przyjechało 73,7 mln cudzoziemców, w tym 16,0 mln turystów i 57,8 mln odwiedzających jednodniowych. Jeśli mowa o wyjazdach turystycznych polaków po Polsce uogólnione wyniki badania GUS wykazały, że w 2014 r. liczba wyjazdów turystycznych zrealizowanych przez polskie gospodarstwa domowe wyniosła $33,0 \mathrm{mln}$, co oznacza, że jedno gospodarstwo domowe uczestniczyło średnio w 2,4 wyjazdach. Spośród wszystkich wyjazdów, większość (ponad 90\%) stanowiły wyjazdy w celach prywatnych. W ciągu roku mieszkańcy Polski odbyli łącznie 59,8 mln podróży (jedna osoba mogła odbyć kilka podróży). Zdecydowanie przeważały podróże krajowe - było ich $48,0 \mathrm{mln}$. W tym podróży krótkookresowych (2-4 dni) było $28,5 \mathrm{mln}$, a podróży trwających 5 dni lub dłużej było 19,5 mln (GUS, 2015).

Spośród wielu tytułów można wyróżnić czasopisma branżowe. Na potrzeby publikacji zainteresowano się przede wszystkim czasopismami branży turystycznej i hotelarskiej.

W tabeli 1 przedstawiono najpopularniejsze magazyny o tematyce turystycznej, są wśród nich dwutygodniki, miesięczniki, dwumiesięczniki i kwartalniki. Popularność tym tytułom przyniosły rzetelne informacje, felietony, reportaże i porady. Dzięki wielu felietonom zamieszczonym na stronach turysta dowie się również o aktualnych trendach w turystyce, jak również gros informacji dla studentów, przewodników, menedżerów, pilotów i gestorów.

Wśród możliwości stosowania mediów elektronicznych w promocji turystyki i hotelarstwa, należy wymienić przede wszystkim portale turystyczne, oraz media społecznościowe. Należy jednak wspomnieć o serwisach branży turystycznej. Wiele tytułów ma swoją stronę w Internecie, nie publikuje się informacji $\mathrm{w}$ formie papierowej, ale każdy klient i interesujący się branżą turystyczną może czytać i sam sobie drukować wybrane fragmenty (tab. 2 i 3 ). 
Wybrane czasopisma branży turystycznej

\begin{tabular}{|l|l|}
\hline \multicolumn{2}{|c|}{ Czasopisma branży turystycznej } \\
\hline Rynek turystyczny & $\begin{array}{l}\text { branżowy miesięcznik, w którym znajdziecie Państwo wiedzę } \\
\text { niezbędną do prowadzenia firmy turystycznej }\end{array}$ \\
\hline $\begin{array}{l}\text { Wiadomości } \\
\text { turystyczne }\end{array}$ & $\begin{array}{l}\text { dwutygodnik informacyjny dla branży turystycznej omawiający } \\
\text { zagadnienia najważniejsze dla biur podróży, agencji turystycz- } \\
\text { nych, menedżerów turystyki w regionach, studentów, pilotów } \\
\text { i gestorów bazy noclegowej }\end{array}$ \\
\hline $\begin{array}{l}\text { Ttg polska - travel } \\
\text { trade polska }\end{array}$ & $\begin{array}{l}\text { informowanie przedstawicieli branży turystycznej oraz czytelników } \\
\text { indywidualnych o aktualnych trendach w dziedzinie turystyki }\end{array}$ \\
\hline Biznes i turystyka & $\begin{array}{l}\text { specjalistyczny dwumiesięcznik poświęcony branży turystyczno- } \\
\text { hotelarskiej }\end{array}$ \\
\hline Poznaj świat & $\begin{array}{l}\text { to miesięcznik turystyczno - podróżniczy, wydawany od 1948 } \\
\text { roku, publikuje relacje z dalekich wypraw znanych podróżników, } \\
\text { jak również oryginalne teksty własnych czytelników }\end{array}$ \\
\hline Extremium & $\begin{array}{l}\text { miesięcznik poświęcony turystyce i sportom ekstremalnym oraz } \\
\text { ludziom (niepokornym, głodnym wrażeń i ryzyka), którzy wybra- } \\
\text { li aktywny styl życia }\end{array}$ \\
\hline $\begin{array}{l}\text { Podróże - magazyn } \\
\text { turystyczny }\end{array}$ & $\begin{array}{l}\text { miesięcznik, komercyjne pismo dotyczące turystyki; ilustrowane } \\
\text { reportaże, felietony, porady }\end{array}$ \\
\hline Poznaj swój kraj & polski miesięcznik krajoznawczo-turystyczny. \\
\hline W górach & $\begin{array}{l}\text { kwartalnik turystyczny - opowiadania o górach, informacje } \\
\text { o górach,(Tatry, Beskidy, Góry Śwwiętokrzyskie) }\end{array}$ \\
\hline Obieżyświat & kwartalnik poświęcony turystyce i podróżom \\
\hline
\end{tabular}

Źródło: opracowanie własne na podstawie slask.travel.pl

Wybrane czasopisma branży hotelarskiej

Tabela 2

\begin{tabular}{|l|l|}
\hline \multicolumn{2}{|c|}{ Czasopisma branży hotelarskiej } \\
\hline Hotelarz & $\begin{array}{l}\text { popularny miesięcznik business-to-business skierowany do branży hote- } \\
\text { larskiej }\end{array}$ \\
\hline Swiat hoteli & $\begin{array}{l}\text { to rozpowszechniane bezpłatnie - czasopismo dla profesjonalistów bran- } \\
\text { ży hotelarskiej - osób podejmujących decyzje w zakresie zarządzania } \\
\text { i wyposażania obiektów noclegowych oraz usługodawców dla sektora } \\
\text { horeca w Polsce }\end{array}$ \\
\hline Hotelarstwo & $\begin{array}{l}\text { miesięcznik B2B adresowany do branży noclegowej, jest magazynem } \\
\text { o charakterze informacyjnym, poradnikowym i narzędziowym. }\end{array}$ \\
\hline Horecanet.p1 & $\begin{array}{l}\text { Serwis opisujący najnowsze wydarzenia oraz zmiany na rynku hotelar- } \\
\text { skim i gastronomicznym. Zawiera aktualne informacje o planach inwe- } \\
\text { stycyjnych, rozwoju tego rynku oraz imprezach branżowych. }\end{array}$ \\
\hline Micepoland & $\begin{array}{l}\text { to jedyne pismo w Polsce opisujące całą branżę, określaną jako meetings } \\
\text { industry oraz wszystkie sektory jej przedstawicieli. W magazynie ukazu- } \\
\text { ją się publikacje dotyczące zarówno rynku eventów, konferencji i kon- } \\
\text { gresów, jak i incentive i podróży biznesowych. }\end{array}$ \\
\hline
\end{tabular}

Źródło: opracowanie własne na podstawie slask.travel.html. 
Dbałość o wizualną atrakcyjność portalu, może się sprawdzić tylko wówczas, gdy informacje będą przekazywane na czas i będą wiarygodne. Ponadto każdy portal kierowany jest do konkretnego odbiorcy, poprzedzony wcześniej segmentacją rynku.

Tabela 3

Wybrane serwisy branży turystycznej

\begin{tabular}{|c|c|}
\hline \multicolumn{2}{|r|}{ Serwisy branży turystycznej } \\
\hline $\begin{array}{l}\text { Aktualności } \\
\text { turystyczne }\end{array}$ & $\begin{array}{l}\text { Czasopismo internetowe wydawane przez Polską Organizację Tury- } \\
\text { styczną. Przeznaczone w głównej mierze dla pracowników regional- } \\
\text { nych i lokalnych ośrodków turystycznych oraz organizacji samorzą- } \\
\text { dowych i szkół wyższych zaangażowanych w rozwój turystyki }\end{array}$ \\
\hline $\begin{array}{l}\text { Dziennik } \\
\text { turystyczny }\end{array}$ & $\begin{array}{l}\text { Magazyn Nowej Turystyki-magazyn internetowy działający od } 2009 \text { r., } \\
\text { zawierający około } 8000 \text { materiałów wskazujących trendy w turystyce, } \\
\text { inspiracje, informacje o najnowszych wydarzeniach, a także wskaźniki } \\
\text { sprawności branży noclegowej }\end{array}$ \\
\hline TUR-INFO.pl & $\begin{array}{l}\text { Internetowy serwis o branży turystycznej dla osób związanych zawo- } \\
\text { dowo z turystyką, a także usługodawców danej branży. Portal koncen- } \\
\text { truje się jest na jak najszybszym przekazie rzetelnych informacji. Za- } \\
\text { wiera działy takie jak: świat turystyki, nowości, oferty poszczególnych } \\
\text { firm. Znajduja się w nim m. in. informacje o zmianach podatkowych } \\
\text { i prawnych, informacje o dotacjach unijnych dla tej branży oraz pro- } \\
\text { gnozy dla poszczególnych sektorów }\end{array}$ \\
\hline $\begin{array}{l}\text { Zarabiaj } \\
\text { na turystyce }\end{array}$ & $\begin{array}{l}\text { Portal Polskiej Organizacji Turystycznej prezentujący ABC turystyki, } \\
\text { prawo w turystyce, a także wiele analiz, badań oraz wydarzeń. Nie } \\
\text { braknie również wielu informacji na temat ośrodków turystycznych, } \\
\text { firm z danej branży oraz edukacji i dobrych praktyk. }\end{array}$ \\
\hline $\begin{array}{l}\text { Turystyka } \\
\text { RP.pl }\end{array}$ & $\begin{array}{l}\text { Serwis branżowy Rzeczpospolitej, który jest częścią wydawnictwa } \\
\text { Presspublica. Prezentuje informacje o branży turystycznej polskiej } \\
\text { i zagranicznej. }\end{array}$ \\
\hline $\begin{array}{l}\text { Ttg central } \\
\text { Europe }\end{array}$ & $\begin{array}{l}\text { Magazyn branży turystycznej powstały w Wielkiej Brytanii. Redakcja } \\
\text { TTG Polska prezentuje informacje od } 1992 \text { roku. W ramach portalu reali- } \\
\text { zowana jest również promocja państw, regionów, samorzadów } \\
\text { i organizatorów turystyki. Pozostałymi produktami wydawniczym są TTG } \\
\text { Dziennik Turystyczny iTTG Travel Trade Television, które również prze- } \\
\text { kazuje wiele informacji dla profesjonalistów branży turystycznej. }\end{array}$ \\
\hline Trendmed.eu & $\begin{array}{l}\text { Portal dedykowany turystyce zdrowotnej i medycznej w Polsce po- } \\
\text { wstał, aby umożliwić głównie turystom z Wielkiej Brytanii, Niemiec, } \\
\text { Szwecji, Norwegii, Dani, Rosji oraz USA i Kanady, dotarcie do Pol- } \\
\text { skiej oferty turystycznej z zakresu zdrowia, zdrowego stylu życia oraz } \\
\text { urody. }\end{array}$ \\
\hline
\end{tabular}

Źródło: opracowanie własne na podstawie rynekinformacji.pl.

Warto tu wspomnieć o portalu Turystyka 24 - profesjonalnym serwisie newsowym dotyczącym branży turystycznej. Prowadzony jest w języku polskim 
i angielskim. Skierowany do kadr kierowniczych, przedstawicieli handlowych, ambasadorów i członków izb turystycznych. Najnowsze wiadomości zamieszczają codziennie na stronie www, jak i a Facebooku, Twitterze i Google+.

\section{Ocena wykorzystania mediów turystycznych i portali}

Media potrafią kształtować naszą opinię, lecz także potrafią manipulować opinią publiczną. Bystry obserwator zauważy, że za pomocą skutecznych reklam, podczas codziennego oglądania telewizji, czytania gazety czy słuchania radia „wtłacza się" nam pewne informacje, do których często powinniśmy się zastosować. Na przykład: jakie powinniśmy mieć kosmetyki, gdzie i w czym prać brudne rzeczy, co czytać, co gotować, jak się ubrać, gdzie wypoczywać, a także gdzie i jak zrelaksować się. Np. ,prawdziwy mężczyzna wie gdzie i jak się ubierać”, „rodzina powinna wybrać właśnie to miejsce na wypoczynek”, „kobieta kupując taki właśnie perfum jest tego warta”, „wybierając to miejsce z pewnością najlepiej wypoczniesz".

$\mathrm{Na}$ portalu internetowym Hotelarz.pl przeprowadzono sondę i zapytano użytkowników, po które czasopisma najczęściej sięgają. Sondę przeprowadzono w okresie 27.09.2005 - 23.11.2005. Poniżej przedstawiono wyniki sondy, rys. 1:

\begin{tabular}{|c|c|}
\hline \multicolumn{2}{|c|}{ SONDA } \\
\hline \multicolumn{2}{|c|}{ Hotelarzu, który z tytuków branżowych czytasz najczęściej? } \\
\hline Biznes i Tunystyka (5) & $2 \% 1$ \\
\hline Doradca Hotelarza (13) & $6 \%$ \\
\hline Hotel Profit (4) & $2 \% 1$ \\
\hline Hotelarz (110) & $52 \%$ \\
\hline Mój Hotel (9) & $4 \%$ \\
\hline Rynek Tunystyczmy (13) & $6 \%$ \\
\hline Śnviat Hoteli (49) & $23 \%$ \\
\hline inmy (9) & $4 \%$ \\
\hline
\end{tabular}

Kącznie oddano 212 głosów

Rysunek 1. Sonda

Źródło: Hotel.pl.

Portal Hotelarz.pl może się pochwalić największym zainteresowaniem wśród branży turystycznej. 


\section{Wykorzystanie mediów przez uczestników turystyki wodnej}

Oprócz takich portali jak: magazyn jachting, akademia-jachtingu.pl, windsurfing, kite.pl, kitesurfing.pl, w lipcu 2016 r. pojawił się nowy serwis dla wielbicieli turystyki żeglarskiej. Sailing.org.pl - to serwis, który ma być aktualizowany przez całą dobę, należy do Polskiego Związki Żeglarskiego (PZŻ). Podzielony jest na siedem sekcji: śródlądzie, morze, sport, technika, kultura, szkolenie i PZŻ. Ma też pasek newsów i sekcję materiałów wideo, a także profile na takich portalach społecznościowych, jak: Facebook, Twitter, YouTube, Instagram i Google+. Zapowiadana jest też wersja na urządzenia mobilne. Jak podaje Sailing.org.pl, na podstawie przeprowadzonego przez siebie badania, w Polsce żeglarstwo uprawia ponad $4 \mathrm{mln}$ osób, dlatego warto było stworzyć witrynę, by podzielić się wieloma informacjami dla tej grupy amatorów turystyki aktywnej.

Z kolei surfski.pl przedstawia SURFSK - biuro podróży dla aktywnych. To tutaj znajdą wiele informacji dla siebie wielbiciele windsurfingu, kitesurfingu, surfingu, żeglarstwa, nurkowania, bowiem turystyka wodna od wielu lat ma coraz więcej wielbicieli.

W województwie zachodniopomorskim opracowano Strategię dla rozwoju turystyki wodnej (2013). Żeglarstwo to współcześnie m.in. rodzaj turystyki i rekreacji. Województwo zachodniopomorskie posiada liczne akweny, które są predestynowane do uprawiania tej formy turystyki. W regionie występuje bogactwo pojezierzy, Zalew Szczeciński, rzeka Odra oraz przede wszystkim Morze Bałtyckie, które pozwalają na uprawianie zarówno żeglarstwa śródlądowego, jak i morskiego.

Wyrazem rozwoju żeglarstwa $\mathrm{w}$ regionie jest powstanie Zachodniopomorskiego Szlaku Żeglarskiego.

Turystyka kajakowa może być uprawiana na znacznej ilości akwenów w regionie. Najpopularniejsze są spływy organizowane na rzekach, ale swoich zwolenników ma także ta forma wypoczynku nad jeziorami. Kajakarstwo jest uprawiane zarówno grupowo, jak i indywidualnie oraz $\mathrm{w}$ gronie rodzinnym, przy czym dominują formy rekreacji realizowane poza strukturami organizacyjnymi. Jego adepci praktykują zazwyczaj trwające od jednego do trzech dni wyjazdy poświęcone określonym szlakom. Ich długość jest związana z charakterem i długością rzek w regionie, co determinuje rozpisaną na jeden do trzech dni marszrutę. Upowszechniła się praktyka korzystania $\mathrm{z}$ oferty firm oferujących 
kompleksowe usługi, w tym dostarczenie sprzętu, noclegi, transport, wyżywienie i dodatkowe atrakcje.

Województwo zachodniopomorskie dysponuje wyjątkowymi warunkami dla nurkowania - sprzyja temu bogactwo jezior oraz możliwości penetracji nurkowych w Bałtyku. Niestety w regionie nurkowanie jest obszarem niszowym turystyki. Amatorzy nurkowania przyjeżdżający do zachodniopomorskiego pochodzą głownie z Polski oraz w mniejszej ilości z Niemiec. Są to przede wszystkim turyści indywidualni, przyjeżdżający na wyjazdy kilkudniowe, krótkie wypady, w ciągu całego roku.

W regionie istnieją kluby nurkowe, centra nurkowe, firmy, usługi szkoleniowe, organizacja imprez turystycznych, sprzedaż sprzętu nurkowego, usługi indywidualne, wypożyczanie sprzętu oraz bazy nurkowe (przede wszystkim nad jeziorem Siecino, Drawsko i Ińsko).

Dzięki swoim walorom przyrodniczym i warunkom naturalnym, województwo zachodniopomorskie jest idealnym miejscem dla uprawiania sportów wodnych, w tym kitesurfingu i windsurfingu.

Duża ilość akwenów wodnych, przybrzeżne płycizny oraz naturalna wietrzność sprawia, że

zachodniopomorskie może być dużą konkurencją dla Półwyspu Helskiego w zakresie tych form turystyki. Wody województwa, zarówno akweny morskie, jak i śródlądowe, można wykorzystywać w różnym stopniu. Obie dyscypliny mogą uprawiać osoby w różnym wieku - zależy to od cech fizycznych oraz umiejętności. O ile windsurfing jest dyscypliną nie wymagającą szczególnych szkoleń, o tyle kitesurfing wymaga przejścia szkolenia. Obie dyscypliny są bezpieczne pod warunkiem przestrzegania zasad bezpieczeństwa. Amatorzy tych dyscyplin skupiają się czasem w klubach, ale generalnie zarówno windsurfing, jak i kitesurfing można uprawiać indywidualnie. Jak jednak w każdym sporcie, możliwość podzielenia się doświadczeniami jest jednym z elementów uprawiania danej dyscypliny w grupie. Grupę odbiorców można określić jako osoby w wieku 15+, turyści indywidualni i grupowi, początkujący i zaawansowani.

To właśnie dzięki portalom internetowym oraz branżowej prasie można nie tylko spotkać podobnych „zapaleńców” turystyki wodnej, ale dowiedzieć się gdzie można uczestniczyć w wyjazdach grupowych, jaki ekwipunek ze sobą zabrać, kto będzie uczestnikiem w zmaganiach turystyki aktywnej a także z jakiej literatury korzystać, by pogłębić wiedzę wcześniej zdobytą. 


\section{Podsumowanie}

Z których mediów najczęściej korzystają klienci usług hotelarskogastronomicznych. Jeśli chodzi o wybór, który jest naprawdę szeroki, to najmniej osób sugeruje się reklamą w kanałach telewizyjnych, choć dziś prawie na każdym z kanałów promuje się polskie miasta i regiony. Często w programach kulinarnych promuje się przysmak regionalny i jednocześnie miejsce, w którym jest ekipa operatorów. Pozytywnym tego przykładem może być program „Okrasa łamie przepisy", w którym najczęściej przedstawione są ciekawe miejsca na wsiach polskich i oferta gospodarstw agroturystycznych. Prowadzący zabiera widzów na kulinarne wyprawy do wybranych zakątków Polski. Z kolei w programie „Makłowicz w podróży” w swych wyprawach dociera do tych najodleglejszych i tych całkiem bliskich zakątków globu, aby odkryć przed widzami wszystkie sekrety sztuki kulinarnej.

O prasie lokalnej można wiele pisać, to ona promuje swój region, poprzez wiele artykułów lokalnych dziennikarzy. Termin „lokalne” akcentuje podmiotowość, nie samego tytułu prasowego, lecz publiczności czytelniczej, która jest właściwym podmiotem skutecznego systemu prasowego. Wobec tego gazeta jest lokalna dlatego, że ci co ją czytają są społecznością lokalną. W zgodzie z tym poglądem to mieszkańcy regionu decydują o tym, czy dana gazeta jest lokalna, czy nie (Rutkiewicz 2009).Można pokusić się o stwierdzenie, że Im mniejszy zasięg pisma i im większy stopień lokalności jego treści, tym większa poczytność mierzona liczbą egzemplarzy przypadających na 100 mieszkańców. Przy wyborze miejsca wypoczynku z Prasy korzysta ok. 26\% turystów, do informacji zaczerpniętej z telewizji przyznaje się $17 \%$ turystów. Niestety biura podróży są sprzedawcą już przemyślanych produktów i dlatego mniej osób konsultuje się w samym biurze. $Z$ tego typu informacji korzysta prawie $6 \%$ turystów, a na targach turystycznych decyzję podejmuje prawie $9 \%$ spośród badanych, co wynika z Raportu Polskiej Organizacji Turystycznej (2008).

Współcześnie mamy do czynienia z pojęciem tzw. „nowych mediów”, tj. Facebook, Google+. Małe i średnie przedsiębiorstwa coraz częściej korzystają z social media, jako narzędzia do osiągania celów biznesowych. Budują tam społeczność wokół swojej firmy. Takie wnioski płyną z badania przeprowadzonego przez portal Firmy.net. O tym, jak istotne dla rozwoju firmy są media społecznościowe świadczy fakt, że aż $61 \%$ badanych przedsiębiorstw przyznało się do ich wykorzystywania w celach biznesowych. Przedsiębiorcy portale społecz- 
nościowe traktują głównie jako narzędzie marketingowe. 45\% firm określa social media jako bardzo przydatne do budowania wizerunku marki. Niewiele mniej, bo $43 \%$ deklaruje, że serwisy społecznościowe są też bardzo użyteczne do promowania oraz sprzedaży produktów. Przydają się też do tworzenia bazy potencjalnych klientów oraz prowadzenia marketingu szeptanego. $34 \%$ badanych uważa $\mathrm{z}$ kolei, że social media idealnie nadają się do budowania społeczności wokół firmy. Dla $27 \%$ jest to zaś najlepsze miejsce do organizacji konkursów. Jednak media społecznościowe to nie tylko czysty marketing. $16 \%$ przebadanych firm wykorzystuje potencjał portali społecznościowych także do rekrutacji pracowników (Badowski, 2011).

Warto promować ofertę turystyczną w wybranych przez siebie mediach, a przeprowadzona wcześniej analiza pozwoli na włáciwie wydane pieniądze. Najlepiej jednak stworzyć własną witrynę, na której możemy na bieżąco zmieniać treść informacji, wstawiać fotografie, co bardziej przemawia do odbiorcy. Nie zapominajmy również o social mediach, które obecnie zawładnęły cały świat i nie sposób pominąć ich przy wyborze jak najlepszej formy promocji naszych działań.

\section{Bibliografia}

Badowski M., 2011. MŚP a media spolecznościowe, http://networkmagazyn.pl/msp-amedia-spolecznosciowe, (data dostępu XII. 2016).

Biełuszko K., Media elektroniczne jako narzędzie promocji turystycznej miasta. w: Prace Naukowe Uniwersytetu Ekonomicznego we Wrocławiu, red., A. Rapacz, nr 379, 2015.

Chorązki W., Sytuacja mediów lokalnych w Polsce w III kwartale 2005 roku, w: Polskie media lokalne na przetomie XX $i$ XXI w. Historia - teoria-zjawiska, J. Jarowieckiego $i$ in. ( red.), Kraków 2007, s. 88-89.

Kępa-Mętrak J., Rola mediów w spoleczności lokalnej, w: Media w procesie ksztaltowania wspólnot lokalnych, Wydawnictwo Urząd Marszałkowski Województwa Świętokrzyskiego, Kielce 2009. S. 9-10.

Rutkiewicz A., Rola mediów lokalnych $w$ rozwoju turystyki przyrodniczej. Studia i Materiały Centrum Edukacji Przyrodniczo-Leśnej, Zeszyt 4(23)/2009.

Rycharska J., Turystyka - 9 najlepszych źródet informacji. (rynekinformacji.pl). 2015 r.

Sapeta J., Prawne podstawy funkcjonowania mediów w Polsce w: Media czwarta wla$d z a$. (http://rola_mediow_w_spoleczenstwie_obywatelskim). $2008 \mathrm{r}$.

Strategia promocji turystyki wodnej $w$ województwie zachodniopomorskim na lata 2013-2020. Stowarzyszenie POMOST - Instytut Gospodarki Morskiej w Szczecinie, Szczecin 2013.

Turystyka w 2014 r. - Główny Urząd Statystyczny, 2015 r.

www.hotelarz. 


\section{The role of media in promoting tourism and recreation}

\section{Summary}

Increased interest in tourist trips in recent years intensified. Rest often we associate with going outside the residence, and finding good deals, sometimes requires contact with a representative of a travel agency, family, friends, look for deals in the directory. It happens that after watching TV or listening to radio ads reflect on the choice of the proposed offer. Currently, a large role is played by the local media, but also electronic media, including social media. The article presents the role of the media in promoting tourism and recreation, and also pointed out the portals of magazines thematically related to the tourist industry. 